日樂理誌 53, 828～835 (1957)

\title{
Tetrahydrozoline の血管收縮作用に関する研究
}

\author{
品、川宏

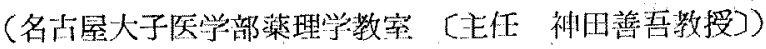 \\ (昭和 32 作 6 月 20 日受的[特])
}

緒 : 言

Tetrahydrozoline (以下Tと略す) は 2-(1,2,3,4-Tetrahydro-1-naphtyl)-imidazoline hydrochloride の化举 棈造を有する Imidazoline 誘導体にして Sahyum and Emerson ${ }^{12}$ (1954) 亿低りその折管收縮作用が登見され，

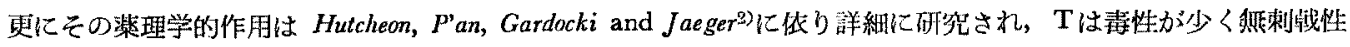

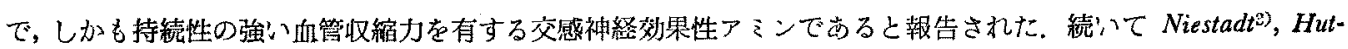

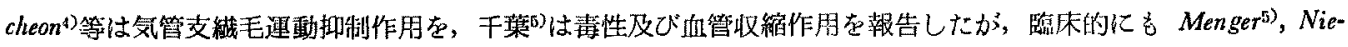
$s t a d t^{3)}$ 始めとして本邦でる数多くの報告が見られる様になつた。

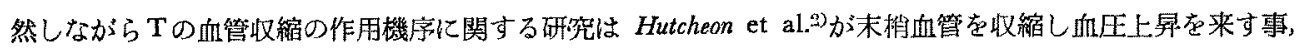

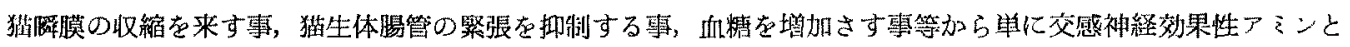
説明した報告以外に見られず，尚幾多解明すべき点が残されている様に思われる，

ここに於て著者はTの血管收綰作用の作用機序を更に明らかにする目的で, 血管中枢の楽理学的新実験法に

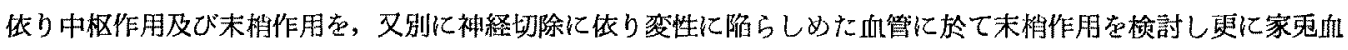
压, 剔出家乘腸管，剔出蛙心に対する作用を梌討した。

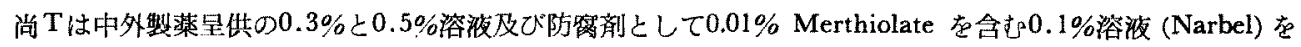
使用した。

\section{実 験 方 法}

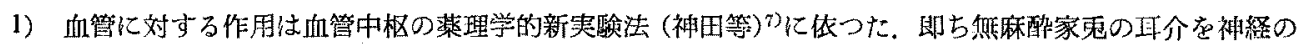

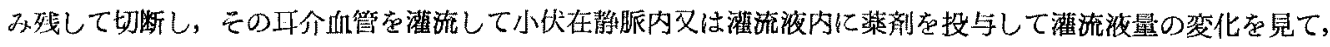

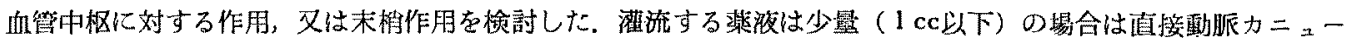

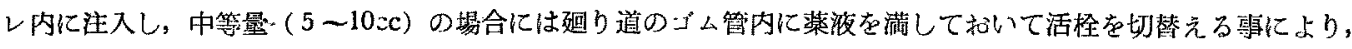

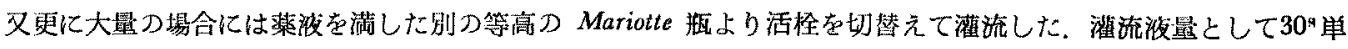

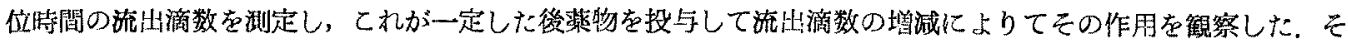
してその增娍は楽物投与前の流出滴数に対する百分比を以て表しだ

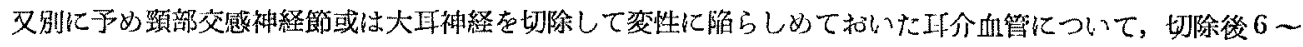
14日亿同栐に菲液を潅流してその作用を見た。

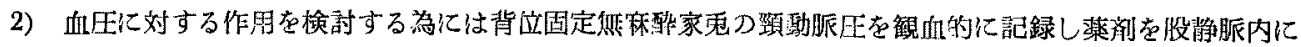
注射した。

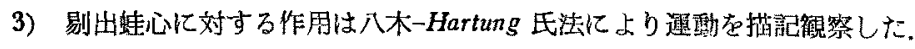

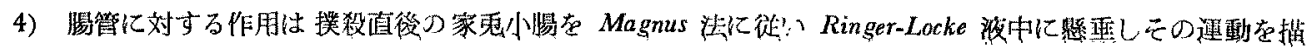
記して検討した， 


\section{実 験 成 綪}

\section{I，血管に対する作用}

\section{1)血管中枢に対する作用}

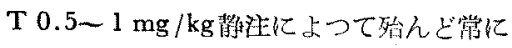
注射直後より一事性の灌流液睢の堌扣, 即方血 管抬張を認め稀に作用の㱠んど認められない事

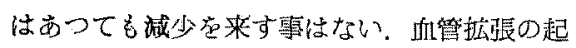

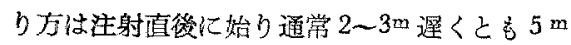
に最高值に達し愁徐々に減少して 8 - 12m 严均

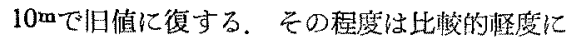
して殆んど20\%以下で $0.5 \mathrm{mg} / \mathrm{kg}$ と $1.0 \mathrm{mg} / \mathrm{kg}$ の血管应張度の平均について $\frac{\mathrm{M}_{1}-\mathrm{M}_{2}}{\sqrt{\mathrm{m}_{1}+\mathrm{m}_{2}{ }_{2}}}$ を 求めて見ると 0.5 にして有意の差は諗められな い(第 1 表).

次にこの血管抬張の作周機序を明ら加にす

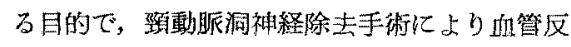

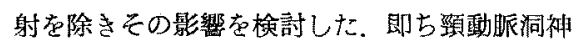

筫 1 表. Tetrahydrozoline の沿管中枢に対する作用。

\begin{tabular}{|c|c|c|c|c|c|}
\hline $\begin{array}{l}\text { 佮䨘 } \\
(\mathrm{kg})\end{array}$ & $\left(\begin{array}{c}\text { 投与最 } \\
(\mathrm{mg} / \mathrm{kg})\end{array}\right.$ & 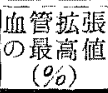 & $\begin{array}{c}\text { 拡張持 } \\
\text { 梳時閐 } \\
\text { (分) }\end{array}$ & 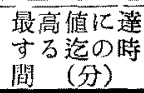 & $\begin{array}{l}\text { 血管反射 } \\
\text { 除去手術 } \\
\text { 後の拡䶂 }\end{array}$ \\
\hline 1.9 & 0.5 & 17.2 & 12 & 2 & 然 \\
\hline 2.0 & $"$ & 9.7 & 10 & 1.5 & \\
\hline 2.0 & "1 & 20.0 & 10 & 3 & 照 \\
\hline 2.0 & "1 & 22.6 & 9 & 4 & 䓡 \\
\hline 1.9 & $" 1$ & 13.8 & 8 & 2 & \\
\hline 2.0 & 1.0 & 23.3 & 10 & 4 & 然 \\
\hline 2.2 & $" 1$ & 12.1 & 9 & 2 & \\
\hline 2.2 & "I & 15.2 & 12 & 5 & \\
\hline 2.1 & 11 & 18.1 & 10 & 2 & $3.3 \%$ \\
\hline 2.1 & 11 & 16.7 & 9 & 3 & 門 \\
\hline 1.8 & "I & 17.0 & 11 & 2 & 暞 \\
\hline
\end{tabular}

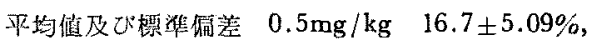
$1.0 \mathrm{mg} / \mathrm{kg} \quad 17.1 \pm 3.74 \%$.

経讜を除去し大動脈神経，迷走神経及び顒部交

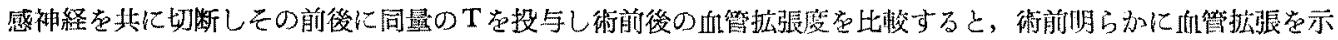
したにも拘らず，術後は最是灌流液量の変動は全く琶められなかつた。

即ち，Tは反射性に血管中权を抑制するものと推祭される。

\section{2) 末梢血管に対する作用}

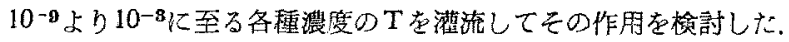

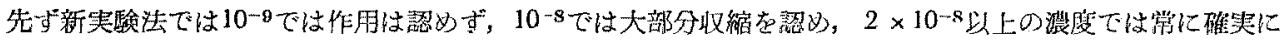

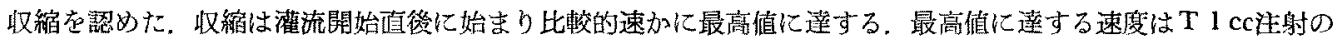

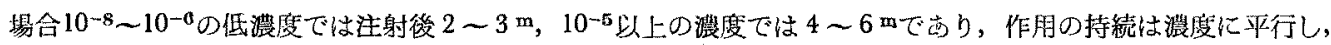

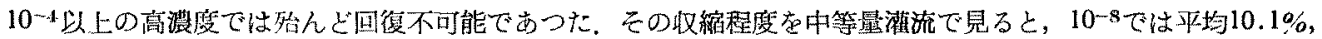

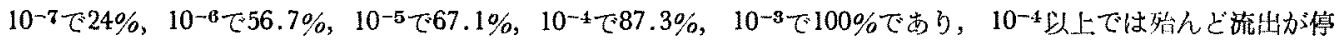

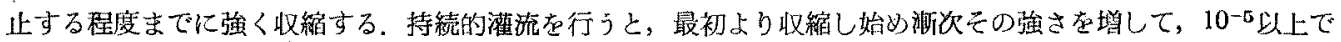

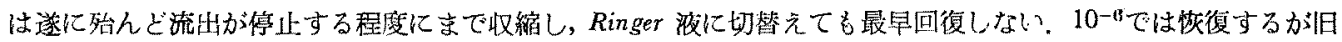

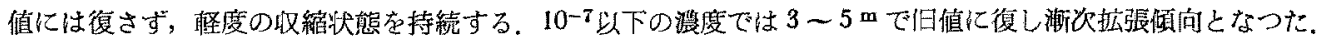

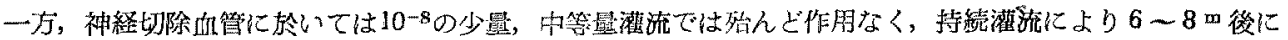

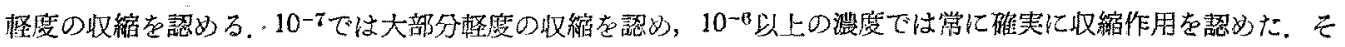

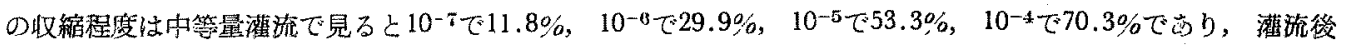

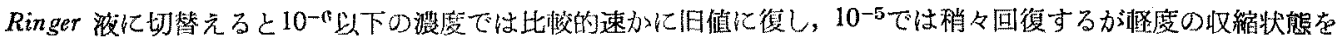
持続し，10-4では殆んど流出が停止する程度まで收縮して最早回復しない，一般にその収縮程弿は神経切除後の

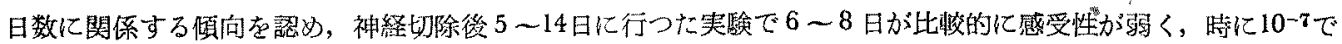

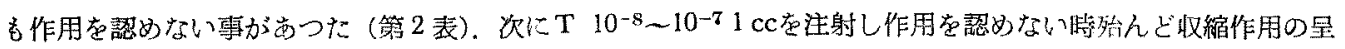

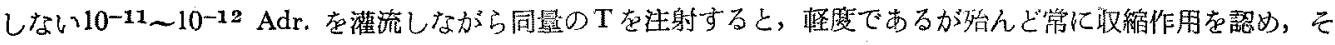
の程度は10-8で9.1\%,10-7で16.1\%であつだ。

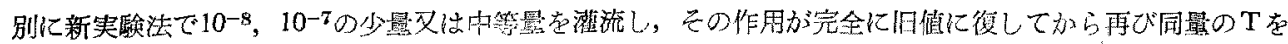

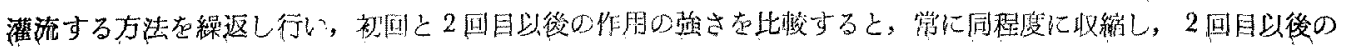




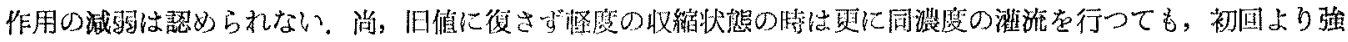
い収縮は認められなかつた。

\section{3）末梢血管に於ける諸種薬物との関係}

a) Adrenaline との関係 (以下 Adr. と略す)

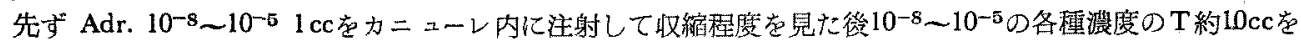

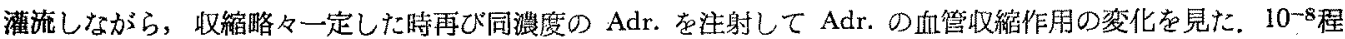

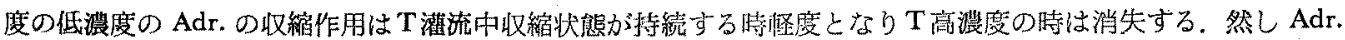
濃度を高くすれぱTの濃度に関係せず同程度の収縮作用を見る。T灌流より Ringer 液に切背え収縮が回復した

第 2 表， Tの末栍性血管作用.

\begin{tabular}{|c|c|c|c|c|}
\hline \multirow[b]{2}{*}{$\mathrm{T}$ 湠度 } & \multirow{2}{*}{ 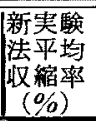 } & \multicolumn{3}{|c|}{ 神経変珄血管 } \\
\hline & & $\begin{array}{l}\text { 切除後 } \\
\text { 日数 }\end{array}$ & $\begin{array}{c}\text { 収縮率 } \\
(\%)\end{array}$ & $\begin{array}{l}\text { 平均収縮 } \\
\text { 率 }(0 \%)\end{array}$ \\
\hline \multirow{3}{*}{$10^{-8}$} & \multirow{4}{*}{10.1} & 5 & 7.8 & \\
\hline & & 7 & 0 & \\
\hline & & 9 & 0 & \\
\hline \multirow{7}{*}{$10^{-7}$} & & 10 & 3.3 & \\
\hline & \multirow{6}{*}{24.0} & 6 & 7.8 & \\
\hline & & 7 & 12.9 & \\
\hline & & 7 & 14.9 & 11.8 \\
\hline & & 8 & 5.3 & \\
\hline & & 12 & 17.8 & \\
\hline & & 5 & 28.0 & \\
\hline \multirow{3}{*}{$10^{-6}$} & \multirow{4}{*}{56.7} & 6 & 28.5 & \\
\hline & & 8 & 33.8 & 29.9 \\
\hline & & 10 & 30.5 & \\
\hline \multirow{5}{*}{$10^{-5}$} & & 14 & 33.9 & \\
\hline & \multirow{4}{*}{67.1} & 7 & 43.9 & \\
\hline & & 9 & 50.5 & 53.3 \\
\hline & & 10 & 60.5 & \\
\hline & & 13 & 58.4 & \\
\hline \multirow{4}{*}{$10^{-4}$} & \multirow{4}{*}{87.3} & 5 & 77.0 & 70.3 \\
\hline & & 7 & 53.9 & \\
\hline & & 9 & 72.9 & \\
\hline & & 11 & 77.3 & \\
\hline
\end{tabular}

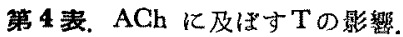

\begin{tabular}{|c|c|c|c|}
\hline \multirow{2}{*}{ T濃度 } & \multicolumn{3}{|c|}{ ACh 孟管㹡震作用 $(\%)$} \\
\hline & $\mathrm{ACh}$ 彗度 & $\begin{array}{l}\text { T灌 } \\
\text { 流能 }\end{array}$ & $\begin{array}{l}\text { T灌 流 } \\
\text { 得 }\end{array}$ \\
\hline $10^{-7}$ & $10^{-7} \mathrm{lcc}$ & 16 & 16.4 \\
\hline $10^{-6}$ & $" 1$ & & 14.0 \\
\hline $10^{-5}$ & "f & & 19.0 \\
\hline $10^{-7}$ & $10^{-0} 0.5 \mathrm{cc}$ & 37 & 34.5 \\
\hline $10^{-0}$ & "y & & 36.0 \\
\hline $10^{-5}$ & "1 & & 35.6 \\
\hline
\end{tabular}

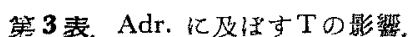

\begin{tabular}{|c|c|c|c|}
\hline \multirow[b]{2}{*}{ T嶎度 } & \multicolumn{3}{|c|}{ Adr. 血管取縮作用 $(\%)$} \\
\hline & Adr. 濃度 & $\begin{array}{l}\mathrm{T} \text { 灌 } \\
\text { 流前 }\end{array}$ & $\begin{array}{l}\mathrm{T} \text { 濩 } \\
\text { 流後 }\end{array}$ \\
\hline $10^{-8}$ & $10^{-8} 1 \mathrm{cc}$ & 23.3 & 16.5 \\
\hline $10^{-7}$ & "I & & 9.0 \\
\hline $10^{-6}$ & $\prime \prime$ & & 2.9 \\
\hline $10^{-5}$ & " & & 0 \\
\hline $10^{-8}$ & $10^{-7} 1 \mathrm{cc}$ & 40.5 & 36.1 \\
\hline $10^{-7}$ & & & 18.1 \\
\hline $10^{-6}$ & & & 17.2 \\
\hline $10^{-5}$ & & & 3.7 \\
\hline $10^{-8}$ & $10^{-6} \mathrm{Icc}$ & 66.5 & 63.1 \\
\hline $10^{-7}$ & & & 43.1 \\
\hline $10^{-6}$ & & & 34.5 \\
\hline $10^{-5}$ & & & 44.0 \\
\hline $10^{-8}$ & $10^{-5} \quad 0.5 \mathrm{cc}$ & 98.5 & 100.0 \\
\hline $10^{-7}$ & $\cdot$ & & 96.0 \\
\hline $10^{-6}$ & & & 100.0 \\
\hline $10^{-5}$ & & & 98.0 \\
\hline
\end{tabular}

第 5 表. Tに及隹す Atr. の影望。

\begin{tabular}{|c|c|c|c|}
\hline \multirow{2}{*}{ Atr. 溜度 } & \multicolumn{3}{|c|}{ T血管収縮作用 $(\%)$} \\
\hline & T 灌度 & $\begin{array}{c}\text { Atr. } \\
\text { 濑流前 }\end{array}$ & $\begin{array}{c}\text { Atr. } \\
\text { 潄流後 }\end{array}$ \\
\hline \multirow{4}{*}{$10^{-6}$} & $10^{-\mathrm{s}}$ & 11.1 & 10.2 \\
\hline & $10^{-\tau}$ & 18.7 & 21.1 \\
\hline & $10^{-6}$ & 32.5 & 30.2 \\
\hline & $10^{-5}$ & 60.3 & 56.5 \\
\hline \multirow{4}{*}{$\begin{array}{c}10^{-5}+ \\
\text { Adr. } 10^{-8}\end{array}$} & $10^{-8}$ & 11.1 & 14.3 \\
\hline & $10^{-7}$ & 18.7 & 21.9 \\
\hline & $10^{-6}$ & 32.5 & 30.5 \\
\hline & $10^{-5}$ & 60.3 & 63.5 \\
\hline
\end{tabular}


時は, 低濃度の Adr.も T灌流前と変りなく収縮した。即ち, 高濃度の $\mathrm{T}$ 灌流の 場合はその 収縮作用が 低濃度の Adr. より強くて最早それ以上に Adr.の収縮作用が現われないが，この場合でも Adr. 濃度を高くすると必 ず収縮作用を見た（第 3 表）。

\section{b) Acetylcholine との関係（以下 ACh と略す）}

ACh $10^{-6} 1 \mathrm{cc}$ 又は 10-7 $0.5 \mathrm{cc}$ を予め注射して血管拡張作用を確認し

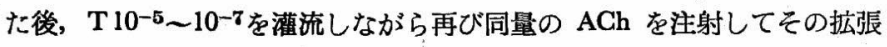
度が $\mathrm{T}$ 灌流に依り変化するか否かを見た。 結果は $\mathrm{ACh}$ の血管拡張は Tに 依り全然影響されなかつた（第 4 表）.

\section{c) Atropine との閶係 (以下 Atr. と略す)}

先ずT $10^{-8}$ 〜 10-6 1 ccを注射し血管収縮の程度を見た後, Atr. $10^{-}{ }_{6}$ 〜10-5を灌流しながらその拡張作用が略々一定した時, 両び同量のTを注 射して収縮状態を見，Atr. 灌流前と比較した．尚，10-の Atr. は血管拡張 作用強い為10-8 Adr. を添加して一定の緊張を保持せしめた. 結果は Tの 収縮作用は Atr. に依り全然影響されなかつた（第 5 表）。

d) Priscol との闆俰 (以下 Pri. と略す)

予め $\mathrm{T} 10^{-8} \sim 10^{-4} 1 \mathrm{cc}$ 動脈カニューレ内に注射しその収縮作用を見 た後, Pri. 10-6〜10-4 灌流しながらその作用が略々一定したならば, 再

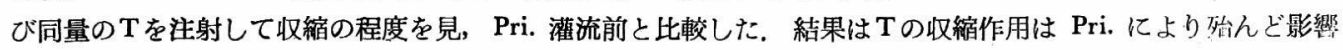
されなかつた（第6表).

\section{II 血代に対する作用}

$0.0005 \mathrm{mg} / \mathrm{kg}$ では変化を見ず， $0.001 \mathrm{mg} / \mathrm{kg}$ では 5〜10 $\mathrm{mm} \mathrm{Hg}$ の血圧上昇を示し， $0.01 \mathrm{mg} / \mathrm{kg}$ で $15 \sim 20$ $\mathrm{mmHg}, \quad 0.1 \mathrm{mg} / \mathrm{kg}$ で 30〜 35 mm Hg， $0.5 \mathrm{mg} / \mathrm{kg}$ で 35〜 40 mm Hg と量を增すに從い昇压度を增したが，1.0 $\mathrm{mg} / \mathrm{kg}$ で 40〜60 mm Hg, $2.0 \mathrm{mg} / \mathrm{kg} て ゙ 35 \sim 50 \mathrm{~mm} \mathrm{Hg}$ と $1.0 \mathrm{mg} / \mathrm{kg}$ 以上は幾ら増量しても昇圧度には変りなく,

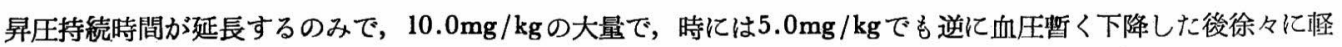
度上昇し持続した. 又との血压下降は $1.0 \mathrm{mg} / \mathrm{kg}$ 以上頻回与えた場合にも見られる. 昇圧発現の仕方は殆んど注 射直後より急激な上昇を示したが Adr. の昇圧発現に比し幾分和くれて上昇しその昇圧程度は T $0.5 \mathrm{mg} / \mathrm{kg}$ と Adr. $2 \gamma / \mathrm{kg}$ とはぼ等しかつたがTの如何なる量も Adr. $5 r / \mathrm{kg}$ 昇圧には及ぱなかつた. 然しながら昇圧持続時間 は Adr. に比し著しく長く T $0.1 \mathrm{mg} / \mathrm{kg}$ は Adr. $5 \gamma / \mathrm{kg}$ に相当し通常 $1 \sim 2 \mathrm{~m}, 0.5 \mathrm{mg} / \mathrm{kg} て 3 \sim 4 \mathrm{~m}, 1.0 \mathrm{mg} / \mathrm{kg}$ で 5 mであつた.

次に同量の $\mathrm{T}$ を反復注射した場合， $0.1 \mathrm{mg} / \mathrm{kg}$ 以下では殆んど同程度の昇圧を示したが, $0.5 \mathrm{mg} / \mathrm{kg}$ 以上特に量の多い程, 又注射間隔の短い頻回注射の 場合に 2 回目以後次第に 昇圧度の減弱を認め, 1.0 $\mathrm{mg} / \mathrm{kg}$ 以上で時に血圧下降を認めた（第 1 図）．然 しながら 1〜 $5 \mathrm{mg} / \mathbf{k g} て ゙ も 10 〜 15 \mathrm{~m}$ 以上の間隔を沶 いて与えた場合には昇圧度の減少或は血圧下降は見 られなかつた。

又別に諸種薬物の $\mathrm{T}$ 血圧上昇に及ぼす影響を検 討したが Pri. 1〜10mg/kg, Tetraethylammonium bromide $5 \sim 10 \mathrm{mg} / \mathrm{kg}$ は T $0.5 \mathrm{mg} / \mathrm{kg}$ の血圧上昇に 殆んど影響なく, 又 Adr. $5 r / \mathrm{kg}$ の血圧上昇は T 1 〜10mg/kgにより影響されることなく殆んど同程度

\begin{tabular}{|c|c|c|c|}
\hline \multirow[b]{2}{*}{ Pri. 濃度 } & \multicolumn{3}{|c|}{$\mathrm{T}$ 血管収縮作用 $(\%)$} \\
\hline & $\mathrm{T}$ 䟴度 & $\begin{array}{l}\text { Pri. } \\
\text { 灌流前 }\end{array}$ & $\begin{array}{l}\text { Pri. } \\
\text { 灌流後 }\end{array}$ \\
\hline \multirow{4}{*}{$10^{-4}$} & $10^{-8}$ & 11.1 & 10.2 \\
\hline & $10^{-7}$ & 18.7 & 19.1 \\
\hline & $10^{-6}$ & 32.5 & 30.0 \\
\hline & $10^{-5}$ & 60.3 & 53.3 \\
\hline \multirow{5}{*}{$10^{-5}$} & $10^{-8}$ & 11.1 & 9.8 \\
\hline & $10^{-7}$ & 18.7 & 16.3 \\
\hline & $10^{-8}$ & 32.5 & 26.6 \\
\hline & $10^{-5}$ & 60.3 & 47.0 \\
\hline & $10^{-4}$ & 82.0 & 73.8 \\
\hline \multirow{5}{*}{$10^{-6}$} & $10^{-8}$ & 11.1 & 12.5 \\
\hline & $10^{-7}$ & 18.7 & 22.6 \\
\hline & $10^{-6}$ & 32.5 & 30.5 \\
\hline & $10^{-5}$ & 60.3 & 40.0 \\
\hline & $10^{-4}$ & 82.0 & 84.0 \\
\hline
\end{tabular}

第 6 表. Tに及ばすPri.の影響。 


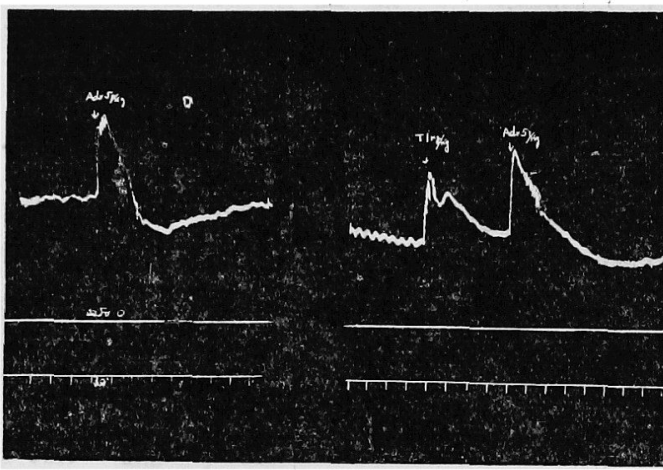

第 2 図。家禹血圧に於けるTのAdr，亿及はす寸影響。 Adr. $5 r / \mathrm{kg}, \mathrm{T} \mathrm{lmg} / \mathrm{kg}$, Adr. $5 r / \mathrm{kg}$, 時標 $/ 30^{\text {s }}$

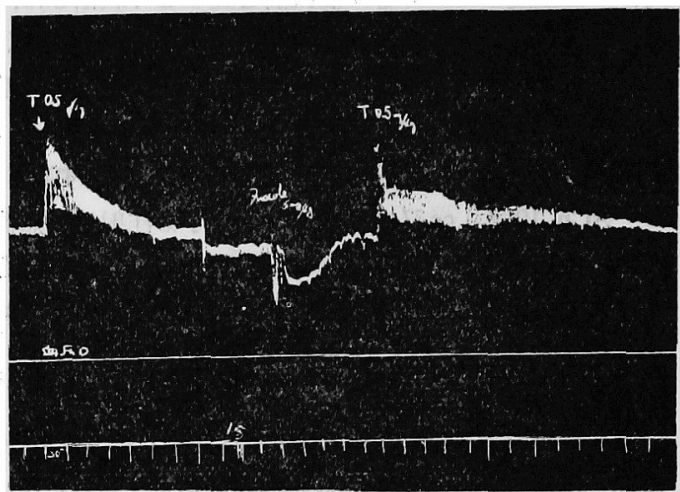

第3 図. 家鬼血圧に於けるPriscol のTに及ばす影響。 T $0.5 \mathrm{mg} / \mathrm{kg}$, Priscol $5 \mathrm{mg} / \mathrm{kg}, \mathrm{T} 0.5 \mathrm{mg} / \mathrm{mg}$, 時標 $/ 30^{4}$.

の血圧上昇を来した（第 $2 ， 3$ 図）。

\section{III. 剔出蛙心滕に対する作用}

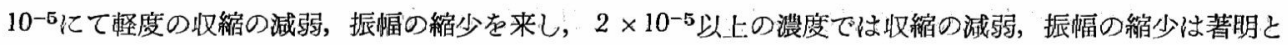

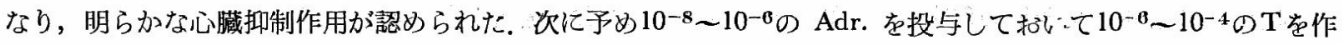
用させたが Adr. 無処置の場合と同様仰抑制作用を認め，作用の減弱或は堌強は認められなかつた（第 4 図).

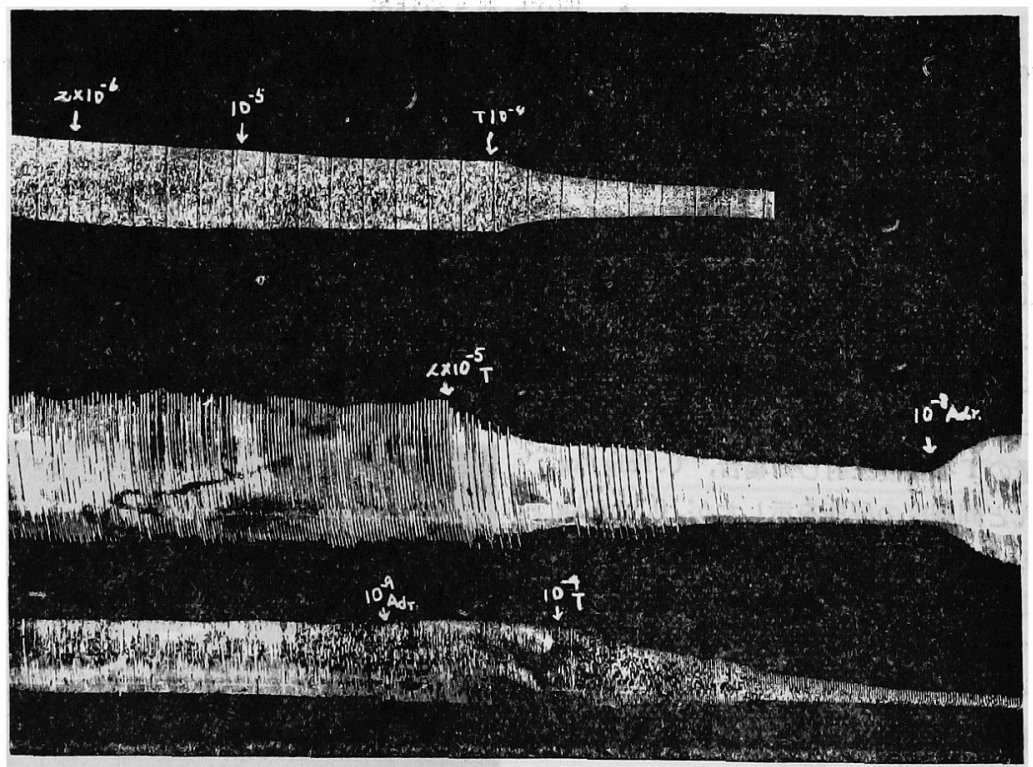

第 4 図．剔出蛙心に対ずるTの作用.

上: T $2 \times 10^{-6}, 10^{-5}, 10^{-4}$, 中: T $2 \times 10^{-5}$, Adr. 10-8, 下: Adr. 10-6, T 10-4.

\section{IV. 剔出家鬼腸管に対する作用}

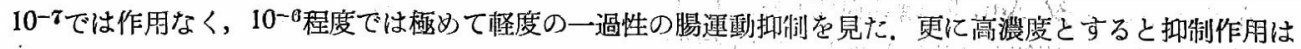
稍々強くなつたがやはり一過性である，この抑制作用は標本が新䱦な程，又 Adr. 加 Ringer 中では強く現れた、 


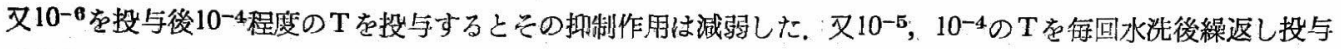
すると，その抑制作用は 2 回目より娍弱，或は殆んど消失するに至つたが，興舊に転ずる事はなかつた。然しと の場合引続いて低濃度の Adr. を与えると強い持続性の 抑制作用を見た（第 5 図），との連用後無作用になつた 時に10-8 程度の低濃度の Adr. を作用させ，引続して同量のTを投与すると，初回投与時の作用には及ばないが，

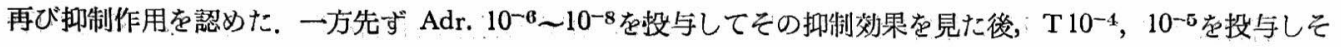

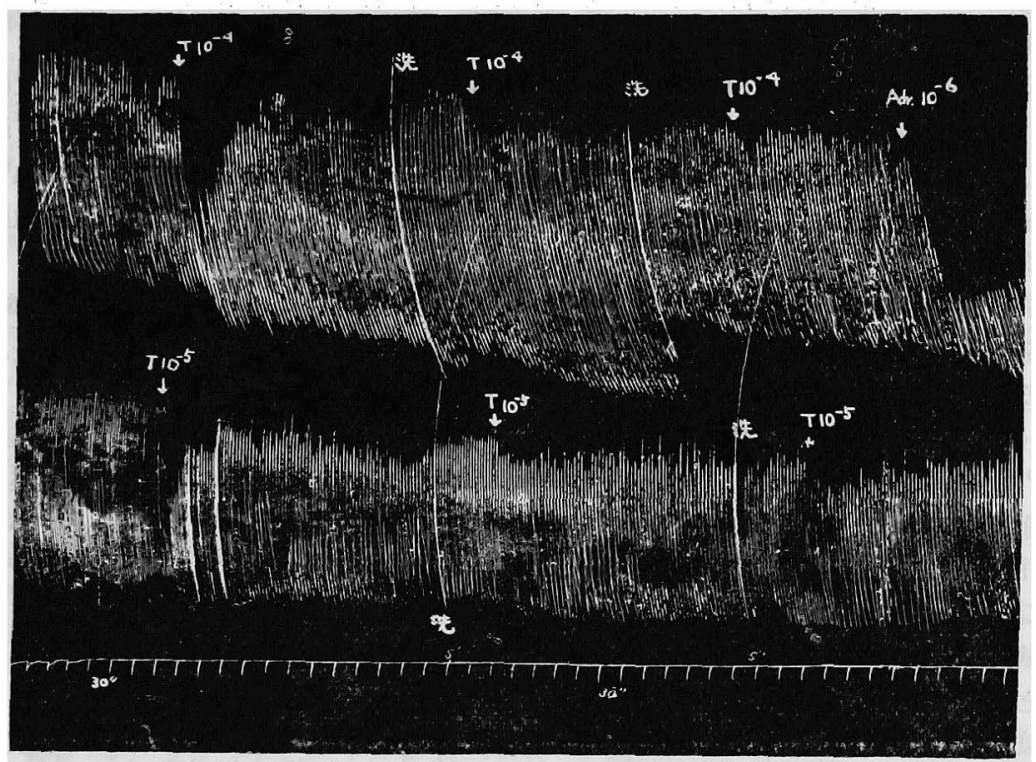

第 5 図. 剔出家兔腸管に対する Tetrahydrozoline の作用（連続投与の場合）.

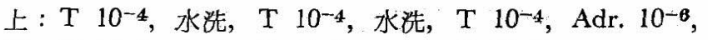
下: $\mathrm{T} 10^{-5}$, 水洗, $\mathrm{T} 10^{-5}$, 水洗, $\mathrm{T} 10^{-5}$.

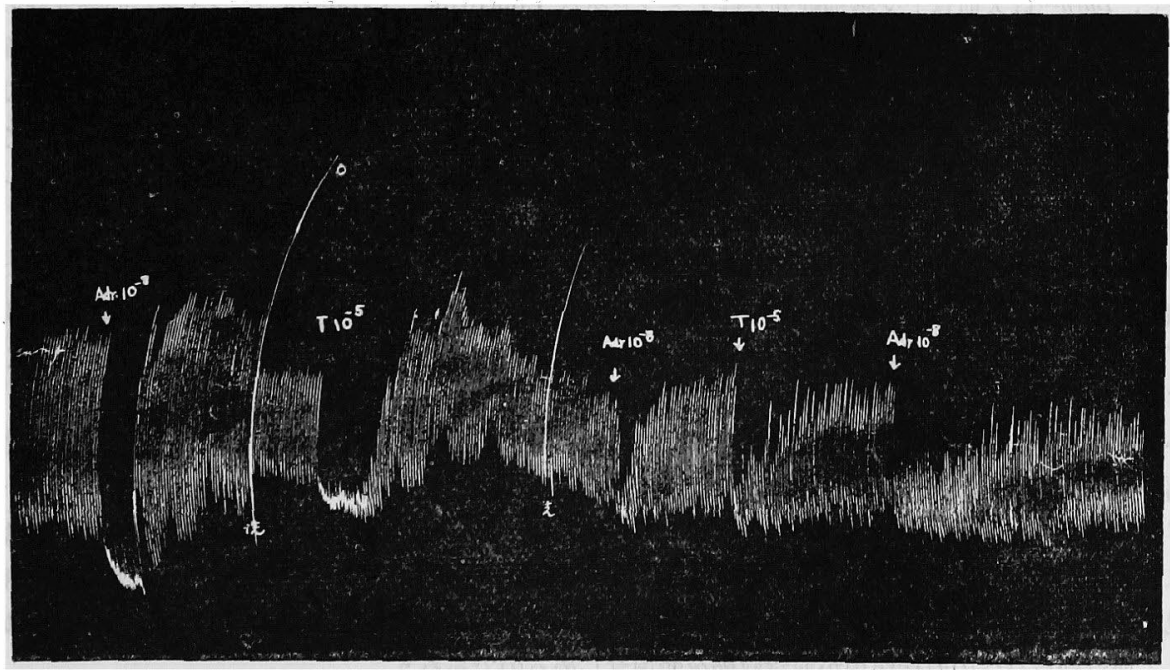

第6 図. 剔出家鬼腸管に於ける Tetrahydrozoline と Adrenaline との関係.

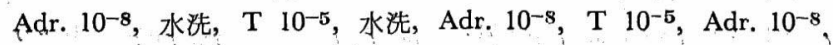




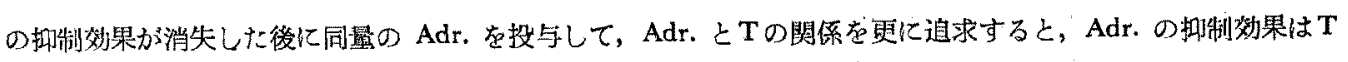

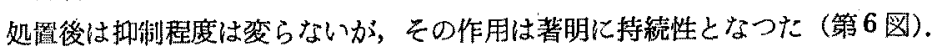

\section{符括及び考察}

著者は Hutcheon et al.22 の報告したTの末佾性血管收縮，血圧上昇作用を血管中权の新実験法，家躳血圧実 験化り追試し，その作用が強力で持続性である事を確珰し，更に神経変性血管，剔出家象晹管，剔出蛙心に対 する作用を検討し，二三の知見を得たので，その作用機序てつき考察を加えて見た。

Tの最少有効量は末梢血管では $10^{-8}$ ，血圧では $0.001 \mathrm{mg} / \mathrm{kg}$ であつて，末梢血管灌流では濃度に平行して収 縮度を增し，10-5以上の濃度では殆んど流出が停止する程度まで強く収縮しだが，血圧実験では最高昇王量は 0.5 1.0mg/kgであり，乙れ以上量を增しても昇王の增加はなく，むしろ血仕下降を見た. 末梢血管では決して

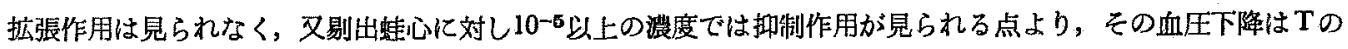
心䑏抑制作用が昇圧を妨げる為であると考える。

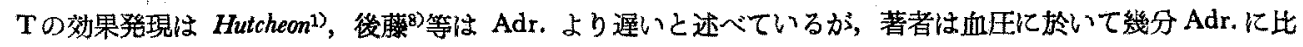

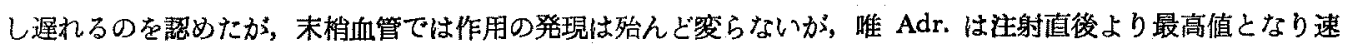

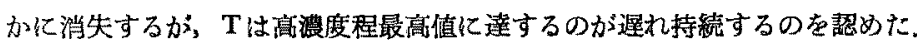

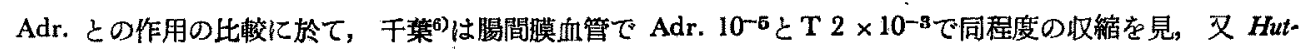
cheon et al.2) は猫, 犬の昇圧效果でT 1 とすると，Adr. は0.025 (1/40) で等高の昇圧を得たと述へているが,

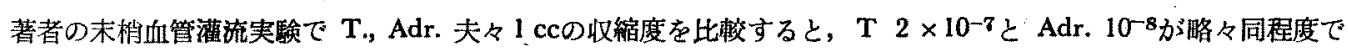

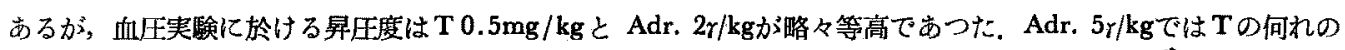
量でる及ばなかつたが，昇圧の持続時間は $\mathrm{T} 0.1 \mathrm{mg} / \mathrm{kg}$ に相当した。

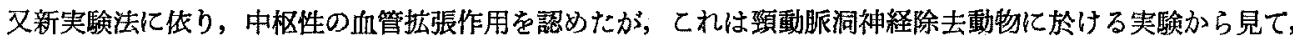
Tが Adr. と同様反射性に血管中权を抑制する事によるるのであると確認した。

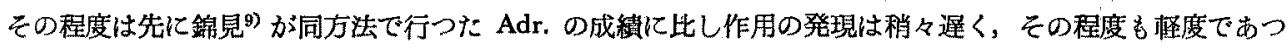
たが，持続時間は長かつた。，又その作用程度で $0.5 \mathrm{mg} / \mathrm{kg}$ と $1.0 \mathrm{mg} / \mathrm{kg}$ との間に有意の差を認めなかつたが，と れは夫々の血圧上昇度が殆んど変りない事から見て当然のととである。

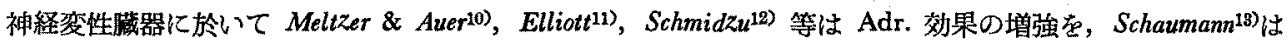
蛙血管で，Burn ${ }^{14}$ 行犬血管で交感神経效果性アミンである Ephedrine，Tyramine につき著しい感受性の低下を 観察しているが，T神経変性血管で㤬軽度の感受性の低下であり，や忏り強力な作用を㷫めだ，又，藏器の剔 出を一種の変性と考えるならば, 剔出腸管では標本が新鮮な程明瞭である一過性の抑制のみにして連続投与する と速汃作用は消失し，感受性㥩しく低下した，乙の場合に Adr. を加えると，可成り活性は回復するが，增 強は見られない，即ち，剔出腸管に於けるTの作用発現にはAdr.の存在が必要であると想像される。一方 Adr. は腸管実験でTの存在沉灰つてその作用は増強はしなかつたが持続性となつた。

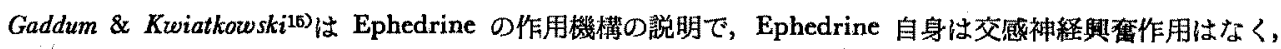
剔出臟器で作用を現わす為には Adr. の存在が必要と考元，乙れを一根拠とした Amine-oxidase 説を提唱した が，Tの腸管作用は，若しTが Amine-oxidase 抑制剂果を持つと仮定すれば説明が容易となる，然しながら果 してTが Amine-oxidase を抑制するが否加は実際に梌討を加えなければならない。

一方Tが持続性の血管作用を示すのに晹管に於ては一過性の抑制を示すのみであるととは腸管筋自身に対す る收縮作用务現われて抑制作用を打消す為之考えざるを得ない。

Tは Adr. の存在しない埸合には弱くはなるが尚強力な血管収縮作用を有し, 又交感神経効果恶断薬 Pri. と

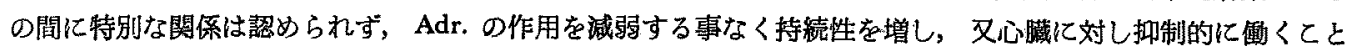
から見て，Tが交感神経初果性で Adr. 受容器に作用するものとは断じ難い、恐らく Amine-oxidase 抑制効果 に加えて血管筋自身への值接作用が血管収縮を発現せしめるのであらう.

「の Tachyphylaxis に就いては Hutcheon et al.2) は大量投与時見られたと述へ，著者息圧実験に於いて $0.5 \mathrm{mg} / \mathrm{kg}$ 以上を短時問内に頻回与えた時作用の減弱，時て血圧下降を見たが僅が10〜15mの聞隔をれるけば作用 


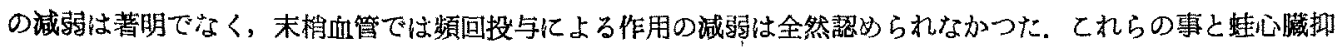
制作用つ成續から推して，Tの大量頻回投与の際は血管が極度に收縮しそれ以上の収縮が起り難く，而も持続時

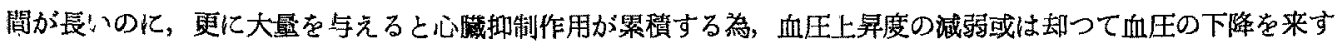
ものと考えられ，真の Tacnyphylaxis とは区别されるべさでないかと考える.

\section{結 論}

Tの作用機序を解明する目的で家禹耳介血管，家电血圧，剔出蛙心及び剔出家秉晹管に対する作用を検討し， 次の結果を得た。

1. Tは強力な末梢栍血管収縮作用，血圧上昇作用を有し，その作用はAdr. 亿比し持結性であり，且その 作用は迮々の自律神経毒により影響されなかつた。.又丁は反射性に血管中枢を抑制する作用を有する事を確認し た。

2. 神経変性血管に於いては軽度の作用の減弱老認めた。剔出腸管では一過性の抑制を来し本作用は Adr. によつて賦活された．剔出蛙心に対しては抑制的に働いた。

3. T.-Tachyphylaxis につき種々検討したが，Tの場合は真の Tachyphylaxis と若えるよりむしろ心䁍抑 制作用の罢䅡と想像する。

4.Tの血管及び晹管作用は Adr. と可成り相違し，Adr. 受容器よりむしろ咀平筋自身に対する直接作用 と Amine-oxidase 抑制によるものであろう.

稿を終るに当り，終始御娒篤なる御指導及び御校閲を晹わつた恩師神田教授に対し梁謝すると共に，種々御 助力, 御助言を頂いた関谷助教授に対し感謝致します。

\section{㵔 女 部}

1) Sahyum, M. \& Emerson, G. : (2)上り刉用.

2) Hutcheon, D.E., P'an, S.Y., Gardocki, J.F. \& Jaeger, D. : J. Pharmacol. \& Exper. Therap. 113, 341 (1955).

3) Neistadt, I. : Arch. Otorhinolaryng. 62, 143 (1955).

4) Hutcheon, D.E. \& Cullen, M.E. : 鼡誌 62, 154 (1955).

5) Menger, M.E. : New York State J. of Med. 55, 812 (1955).

6) 千賲：ナーベル交献集 P 2, 中外製蒋.

7) 神田, 䤼見, 武田：日薬理誌 52，577 (1956).

8) 後藤，他：治療 38, 123 (1956).

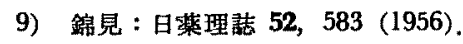

10) Meltzer, S.J. \& Auer, C.H. : Amer. J. Physiol. 11, 28 (1904).

11) Eltiott, T.R. : J. Physiol. 32, 401 (1905).

12) Schmidza; K. : Arch. exper. Path. Pharmak. 104, 254 (1924).

13) Schaumann, D.: 同誌 138, 208 (1928).

14) Burn, J.H. : J. Pharmacol. \& Exper. Therap. 46, 75 (1932).

15) Gaddum, J.H. \& Kwiatkonski, H. : J. Physiol. 94, 87 (1938). 